\title{
Antikorruption - big bang-ansatsen
}

\section{Bo Rothstein}

SAMMANDRAG: Åtgärder mot korruption har hamnat allt högre på den internationella dagordningen för ekonomisk utveckling. I den här artikeln kritiserar Bo Rothstein den dominerande antikorruptionspolitiken som utifrån idéer om "god samhällsstyrning" försöker inleda inkrementella förändringsprocesser. Med hjälp av spelteori och institutionella teorier om villkoren för kollektiv handling visar han hur denna politik underskattar de institutionella hindren för en sådan enkel inkrementell förändring i genomkorrumperade samhällen. Föreskrivna punktinsatser kan i stället få motsatt effekt när de utlovade förändringarna uteblir. Vad som krävs för att verkligen få bukt med systemisk korruption är inget mindre än en big bang-ansats, en genomgripande förändring av de grundläggande handlingsmönstren i ett samhälle. Genom att titta närmare på hur Sverige kom till rätta med en grasserande korruption under I8oo-talet framhåller Rothstein de indirekta positiva effekter som uppnåddes med ett allmänt program för att implementera universalism och opartiskhet i alla led i statsförvaltningen.

NYCKELORD: korruption; god samhällsstyrning; opartiskhet; statsförvaltning; effektiva institutioner; Sverige.

PUbLiCERINGShistorik: Originalpublicering. Artikeln är en översättning och bearbetning för svensk publik av manus skrivet på engelska.

во ROTHSTEIN är professor i statsvetenskap vid Göteborgs universitet och är huvudansvarig för forskningsprogrammet Quality of Government Institute (QoG).

E-POSTADRESS: bo.rothstein@pol.gu.se

\section{FÖRSLAG PÅ KÄLLANGIVELSE:}

Rothstein, Bo (2013) "Antikorruption - big bang-ansatsen", i Arkiv. Tidskrift för samhällsanalys, nr I, s. 7-36.

DOI: http://dx.doi.org/IO.I3068/2000-62I7.I.I

(C) Bo Rothstein/Arkiv förlag \& tidskrift 2013 (publicerad 2 september 20I3)

Artikeln distribueras enligt en upphovsrättslicens från Creative Commons: Erkännande-Ickekommersiell-IngaBearbetningar 3.0 Unported, som medger fri ickekommersiell användning och spridning i oförändrat skick så länge källan anges. 
Arkiv. Tidskrift för samhällsanalys är en sakkunniggranskad vetenskaplig tidskrift för samhällsvetenskap och historia. Samtliga artiklar publiceras fritt tillgängliga på:

www.tidskriftenarkiv.se

(beständig länk, DOI: http://dx.doi.org/IO.I3068/2000-62I7)

Den här artikeln finns tillgänglig i följande format:

PDF \& HTML: via beständig länk, DOI: http://dx.doi.org/IO.I3068/2000-62I7.I.I EPUB: ingår i e-boksutgåva av numret (släpps i slutet av 2OI3), ISBN: 978 9I 79242503

TRYCK: ingår i bokutgåva av numret (släpps i slutet av 20I3), ISBN: 978 9I 7924 25I O

Grafisk utformning och sidnumrering är identisk i pdf och tryck.

Samtliga artiklar i nr I (2013) nås via beständig länk, DOI: http://dx.doi.org/I0.13068/2000-6217.I

Arkiv. Tidskrift för sambällsanalys ISSN: 2000-62I7 (för elektronisk resurs)

ISSN: 2000-6225 (för tryckta nummer)

ges ut av

Stiftelsen Arkiv för främjande och spridning av samhällsvetenskaplig och historisk forskning

genom

Arkiv förlag \& tidskrift

Box 1559

SE-22I OI Lund

ВESÖK: L Gråbrödersg 3 c, ipg

TEL: O46-I3 3920

ARKIV FÖRLAG: arkiv@arkiv.nu·www.arkiv.nu

TIDSKRIFTEN ARKIV: red@tidskriftenarkiv.se · www.tidskriftenarkiv.se

ANSVARIg UTGIVARE \& CHEFREDAKTÖR: Sven Hort

ADMINistrativ RedAKTÖr: David Lindberg

ReDAKTörer: Paavo Bergman, Lisa Kings, Zhanna Kravchenko 


\title{
Antikorruption - big bang-ansatsen
}

\author{
BO ROTHSTEIN
}

\section{Vad saknas i den politiska ekonomin?}

I en nyligen utgiven Handbook of Political Economy ingår ett kapitel med rubriken "Vad saknas i den politiska ekonomin?" skrivet av en av de ledande forskarna inom vad som har blivit känt som "nyinstitutionell ekonomi", nämligen Douglass C. North. ${ }^{\mathrm{I}}$ Inbjuden av bokens redaktörer att ge några synpunkter på vad som har åstadkommits på detta forskningsområde har han faktiskt några välvilliga ord att säga om de andra femtioåtta kapitlen i den här omfångsrika handboken. Men han kritiserar också den politiska ekonomin för att inte ta upp "en rad större frågor". Den viktigaste formulerar han på följande sätt: "Varför är inte alla länder i världen utvecklade industrinationer? Varför skapar de parlamentariska församlingarna en stabil äganderätt och en rättsstat i den utvecklade delen av världen men inte i utvecklingsländerna?" (North 2006: I003). Han säger också att "vi måste ta reda på vad det är som gör fattiga länder som inte utvecklas så stabila”. Varför bildar, med andra ord, kombinationen av fattigdom och dysfunktionella institutioner ett så stabilt jämviktstillstånd?

I. North tilldelades ekonomipriset till Alfred Nobels minne 1993.

Två tidigare versioner av den här artikeln, riktade till en internationell publik, har publicerats på engelska som "Curbing Corruption: The Indirect 'Big Bang' Approach", i Bo Rothstein, The Quality of Government. Corruption, Social Trust, and Inequality in International Perspective, University of Chicago Press 20II, och "Anti-Corruption: The Indirect 'Big Bang' Approach", i Review of International Political Economy, volym I8, nr $220 \mathrm{II}$ (http://dx.doi.org/I0.1080/09692291003607834). 
Norths förklaring till detta "svarta hål" i den politiska ekonomin är dubbel. För det första tar man i nu vanliga angreppssätt inom den politiska ekonomin "inte på ett adekvat sätt upp problemet med ickeinkrementell förändring" (2006: IOO4), och för det andra inriktar sig nästan alla politisk-ekonomiska analyser på de formella institutionernas verkningar men försummar de informella institutioner som för North är lika viktiga och mer intressanta. Eftersom korruption i hög grad är en informell institution som drivs av agenters föreställningar om andra agenters föreställningar är det slående att det saknas ett kapitel om korruption eller liknande frågor i den här handboken. Går man igenom sakregistret till den elvahundra sidor stora handboken lägger man förundrat märke till att sådana frågor inte tycks spela någon större roll på den politiska ekonomins område. Det är, som Michael Johnston har påpekat, påfallande att "amerikansk statsvetenskap som institutionaliserad disciplin under flera generationer har varit orubbligt ointresserad av korruption" (Johnston 2006: 809). En granskning av ett antal nyare "handböcker" i statsvetenskap och offentlig förvaltning visar att korruption, klientilism och liknande exempel på dysfunktionella politiska institutioner nästan aldrig nämns (Dryzek, Phillips \& Honig 2006; Moran, Rein \& Goodin 2006; Peters \& Pierre 2002; Rhodes, Binder \& Rockman 2006).

Det är egendomligt eftersom det numera finns ett ganska övertygande empiriskt stöd för att kvaliteten på ett lands politiska institutioner bestämmer dess ekonomiska och sociala utveckling (Holmberg, Rothstein \& Nasiritousi 2009; Mauro 1995; Rose-Ackerman 2004). Det förs förvisso en livlig diskussion om vad som bör betecknas som institutioner "av hög kvalitet", men man kan inom både statsvetenskap och nationalekonomi tala om en ökad fokusering på vikten av institutioners kvalitet. Det tycks också vara så att korruption förstör ett samhälles sociala kapital (Dinesen 2006; Rothstein \& Eek 2006; You 2006). Och tillsammans med "subjektivt hälsotillstånd" har korruption en mycket negativ inverkan på människors "livstillfredsställelse" (Helliwell 2006). Såväl i det internationella biståndets värld som inom akademisk forskning om fattigdom och ekonomisk tillväxt i utvecklingsländerna har det tidiga I990-talets strängt marknadsorienterade "Washingtonsamförstånd” i stor 
utsträckning ersatts av vad som nu kan kallas "god samhällsstyrning”, där åtgärder mot korruption, klientilism och dylikt spelar en dominerande roll (Rodrik 2007; B. Smith 2007).

Jag tänker behandla korruption och antikorruptionspolitik utifrån de av North framförda föreställningarna om "icke-inkrementell förändring" och vikten av "informella institutioner". Artikeln är strukturerad på följande sätt: I den första delen presenterar jag ett sätt att se på korruption och antikorruption som bygger på institutionella teorier, där huvudargumentet är att korruption inte ska uppfattas som ett "principal-agentproblem" utan som en "social fälla" eller som något som har med "kollektivt handlande" att göra. Jag söker här förena insikter om korruption (och liknande praktiker) från tre olika teoretiska angreppssätt, nämligen "nyinstitutionell ekonomi" (Shirley 2005), "evolutionär spelteori" (Aumann \& Dreze 2005; Young 1998) och "historisk institutionalism" (Steinmo \& Thelen 1992). På denna grund utvecklar jag sedan en kritik av det dominerande inkrementella sättet att se på antikorruptionspolitik. I tredje delen presenteras ett alternativt perspektiv på antikorruption som jag kallar för big bang-ansatsen. Relevansen av den ansatsen belyses av den framgångsrika antikorruptionspolitik som fördes i Sverige under I8oo-talet. Artikeln slutar med några funderingar över hur man ska förstå en sådan icke-inkrementell förändrings natur och möjligheter.

\section{Korruption. Det institutionella betraktelsesättet}

Standarddefinitionen av korruption i offentlig förvaltning tycks numera vara "missbruk av ett offentligt ämbete för privat vinning". Detta är en problematisk definition eftersom den inte innehåller någon normativ bestämning av "missbruk". Det blir följaktligen den specifika kulturella miljön som avgör vad som är korruption. Ett alternativ som har föreslagits av Oskar Kurer samt Rothstein och Teorell har fördelen att det bygger på en universell norm för offentliga tjänstemän, nämligen opartiskhet, med vilket avses icke-diskriminering i utövandet av offentlig makt. Korruption handlar alltså om att "en innehavare av ett offentligt ämbete bryter mot principen om opartiskhet för privat vinnings skull” (Kurer 2005: 230; jfr Rothstein \& Teorell 2008). Opartiskhet kan i sin tur definieras 
på följande sätt: "förvaltningsorganen [får] i sin verksamhet inte ... låta sig vägledas av andra intressen än dem de är satta att tillgodose och inte heller grunda sina avgöranden på hänsyn till andra omständigheter än sådana som enligt gällande författningar får beaktas vid prövningen av ett ärende" (Strömberg 2000: 72); eller som Cupit skriver: "Att handla opartiskt är att inte låta sig påverkas av vissa faktorer, som särskilda relationer och personliga preferenser. Det är att behandla människor lika oberoende av personliga relationer och personliga sympatier och antipatier" (Cupit 2000: 13).

Den mest etablerade föreställningen om hur man ska förstå korruption är den så kallade principal-agent-modellen (Aidt 2003; Teorell 2007). Här ses korruption som ett brottsligt beteende från vissa agenter som anförtrotts uppgiften att handla på en (hederlig/välvillig) principals vägnar. Den välvillige principalen kan till exempel vara en minister och de kriminella/korrupta agenterna kan vara de statliga tjänstemännen. Ett problem med ett sådant synsätt är att det i ett genomkorrupt system kan vara svårt att slå fast vem en sådan välvillig principal är. De politiska eliterna är exempelvis ofta de som har mest att vinna på ett korrupt system och har alltså ingen motivation för att ändra på systemet (Johnston 2005; Teorell 2007). En annan idé i den här ansatsen är att det är "folket" som är (den hederlige och välvillige) principalen och de politiska ledarna som är de korrupta agenterna. Svårigheten här är att det i ett korrupt system helt enkelt inte finns några belägg för att demokratiska val motverkar korruption (Teorell 2007). Korrupta politiker har tvärtom ofta goda möjligheter att bli omvalda. Och allmänt har agenter längst ner i ett korrupt system, till exempel skattebyråkrater eller poliser, inga skäl att avhålla sig från korrupta praktiker eftersom ingenting kommer att förändras även om de själva börjar bete sig hederligt. Det är som bekant ingen mening med att vara den ende hederlige spelaren i ett "ruttet spel" eftersom ett välvilligt beteende från en eller några få agenter inte kommer att leda till någon förändring. Det betyder att $\mathrm{i}$ ett politiskt system som plågas av systematisk korruption kommer man sannolikt inte att finna några välvilliga "principaler" vare sig högre upp eller lägre ner i systemet.

Och om korruption verkligen fungerade enligt principal-agentmodellen skulle det vara lätt att utplåna det genom att bara förändra 
incitamenten: principalerna ökar det negativa utfallet av bedrägeri och korruption (inklusive risken för att bli ertappad) till en punkt där rädslan för att bli ertappad är högre än den girighet som får agenterna att ägna sig åt korruption. Ett samhälle där rädslan är större än girigheten fungerar väl. Nackdelen med här synsättet är att problemet förskjuts till kollektivt handlande på en andra nivå (Rothstein 2000; Teorell 2007). Varje enskild agent kan mycket väl inse att hon skulle vinna på att korruptionen utplånas, men eftersom hon inte kan lita på att de flesta andra agenter kommer att avstå från korrupta bruk har hon ingen anledning att till exempel avstå från att ge eller kräva mutor. Enda skälet till att hon skulle göra det var att det fanns en institution som såg till att de flesta andra inte ägnade sig åt korruption (Rawls 1996: 235). Men att inrätta en sådan trovärdig institution är i sig ett problem för det kollektiva handlandet (Lichbach 1997). Problemet med korruption sett ur detta institutionella perspektiv är således att det är ett självförstärkande fenomen (Aidt 2003; Karklins 2005; Uslaner 2008). Enkelt uttryckt visar empirisk forskning generellt att "har ett system väl upprättats så tenderar det att bestå". Eller som Bardhan uttrycker det: "korruption utgör ett exempel på vad som kallas frekvensberoende jämviktstillstånd, och vår förväntade vinning av korruption beror till avgörande del på antalet andra människor som vi räknar med ska bete sig korrupt (Bardhan 1997: 133I).

Ännu en viktig faktor måste nämnas. Även om korruption uppenbarligen har kulturella inslag bör det inte ses som kulturellt bestämt. Som visats i olika studier, till exempel i Hilton Roots (1996) undersökning av de framgångsrika antikorruptionskampanjer som drivits i Hongkong och Singapore, är kvaliteten på politiska och juridiska institutioner inte kulturellt bestämda. Dessa samhällen har som bekant upplevt en anmärkningsvärt hög ekonomisk tillväxt, och Root visar övertygande att en förutsättning för detta har varit den framgångsrika kamp mot korruption som inleddes på 1970-talet. I ett jämförande perspektiv utmärks dessa länder av en relativt låg grad av korruption. I den senaste mätningen av Transparency International fick Singapore siffran 9,3 på den tiogradiga skalan, som placerade det på femte plats jämte Sverige, medan Hongkong hamnade på fjortonde plats med 8,2. Transparency Internationals mätning visar att närbelägna länder, som rimligen kan sägas tillhöra samma 
kulturella sfär, är betydligt mer korrupta. Kina hamnar på femtionionde plats med 3,5 medan Indonesien kommer på nittiosjätte plats med I,9 och Malaysia på trettiotredje plats med $4,9 .^{2}$

Vi kan av dessa skillnader mellan närbelägna länder dra slutsatsen att graden av korruption inte nödvändigtvis är kulturellt bestämd (Hodess, Banfield \& Wolfe 200I). Enligt Rasma Karklins analys brukar "vanliga människor" i korrupta system inte internalisera korrupta praktiker som moraliskt legitima handlingar. I stället fördömer de korruption som moraliskt fel och beskyller "systemet" för att tvinga dem att ägna sig åt korruption; de befinner sig med andra ord i ett slags "social fälla" (Karklins 2005). I övertygelsen om att de flesta andra agenter inte skulle vilja ägna sig åt korrupta praktiker vill de helst inte ta emot eller ge mutor (B. Smith 2007: 19I). Men eftersom de flesta andra faktiskt gör det så tvingas de till ett korrupt beteende.

Detta är viktigt eftersom det klargör att traditionella föreställningar om rationalitet på mikronivå visserligen gör det möjligt för oss att förstå den "inre" självförevigande logiken i ett korrupt (och icke-korrupt) jämviktstillstånd, men inte är till någon större hjälp om vi vill förklara varför olika samhällen hamnar i så olika jämviktstillstånd (givet att nyttobaserad rationalitet är ett begrepp med universell räckvidd). Man kan inte heller med hjälp av dem förklara variationer mellan olika system. I en kritik av det program för "god samhällsstyrning" som på senare år har lanserats av många internationella biståndsorganisationer hävdar Bukovansky, att om antikorruptionsdebatten "fortfarande domineras av en liberal, individualistisk rationalism så förmår den inte att på ett adekvat sätt formulera och helt utforska nödvändigheten av moralisk och politisk handling i sökandet efter det kollektiva goda" (Bukovansky 2006: 20I). Detta skapar förvisso ett problem: om variationen i graden av korruption inte kan förklaras vare sig med traditionella nyttobaserade föreställningar om ekonomisk rationalitet eller med hänvisningar till kulturen, vad ska man då tillgripa för idéer om vad det är som styr handlandet? En väg ut ur det här dilemmat har anvisats av spelteoretikerna Robert Aumann och Jacques Dreze, som har hjälpt oss att för-

2. Siffror från http://archive.transparency.org/policy_research/surveys_indices/cpi/20o8, Corruption Perceptions Index 2008. 
stå förhållandet mellan rationalitet $\mathrm{i} n$-personersspel och variationer $\mathrm{i}$ det samlade resultatet. De lanserar i en uppsats med den talande titeln When All is Said and Done, How Should You Play and What Should You Expect? begreppet "interaktiv rationalitet". Deras viktiga idé är att man i en analys av situationer med strategisk interaktion bör beakta inte bara att alla agenter kan vara rationella, utan också att det är den "verklighetskontext" i vilken spelet sker som är avgörande för agenternas val av strategi (Aumann \& Dreze 2005: 9). En sådan "verklighetskontext" är inget annat än den institutionella miljö som omger agenterna. I vårt fall beror alltså beteendet på hur de existerande institutionerna präglar agenternas "ömsesidiga förväntningar”, till exempel förväntningarna om huruvida de andra agenterna kommer att ta del i det korrupta utbytet eller ej. Eller som John Rawls formulerade det i sin "moderna klassiker" En teori om rättvisa:

Ty även om människorna vet att de alla har samma sinne för rättvisa och att var och en av dem vill hålla sig till de befintliga arrangemangen, kanske de ändå inte har fullt förtroende för varandra. De kan misstänka att somliga inte utför sin del av samarbetet, och då blir det frestande att själv låta bli att utföra sin andel. Den allmänna medvetenheten om denna frestelse kan så småningom få systemet att bryta samman. Misstanken att andra inte fullgör sina plikter och förpliktelser förstärks av att det, när reglerna inte tolkas och genomdrivs av någon auktoritet, blir särskilt lätt att komma på ursäkter för att bryta mot dem (Rawls I996: 235).

Enligt Rawls kan man lösa det problemet genom att inrätta opartiska institutioner som försäkrar agenterna om att de flesta "andra" kommer att "fullgöra sina plikter". Den specifika frågan är hur man ska föreställa sig att en agent i ett samhälle präglat av systemisk korruption tänker när hon bestämmer sig för om hon ska delta i det korrupta utbytet eller ej. Vi måste föreställa oss en agent som har levt hela sitt liv i ett samhälle där korruptionen är "systemisk". Det är ett system där behovet att ge och ta emot mutor för att erhålla vad som bedöms vara nödvändiga tjänster och/eller en nödvändig ekonomisk standard är så djupt inrotat i de flesta agenters "mentala kartor" att det har blivit en informell institution. När du går till läkaren, när du träffar läraren, när du lämnar ett anbud på ett offentligt kontrakt, när du behöver tillstånd för att driva en restaurang, 
när du ska ta examen på universitetet, när du söker jobb i den offentliga sektorn, när du blir stoppad av polisen -"standardproceduren" är då att betala mutor eller utföra någon liknande illegal handling (dessa exempel är hämtade från två nyare antropologiska verk om korruption: D. Smith 2007; Wrong 2009). Du har gjort så i hela ditt liv, precis som alla andra du känner, och "alla vet" att man ska handla på det sättet. För att ge ett exempel: FN:s utvecklingsprogram (UNDP), som är ansvarig för FN:s årliga Human Development Report, genomförde 2002 en "regional studie" av Bosnien-Hercegovina. I rapporten ingår ett avsnitt om korruption där det presenteras en undersökning som visar att cirka 70 procent av landets befolkning tror att de lokala myndigheterna är "grovt korrupta". Det är kanske inte särskilt överraskande, men faktum är att en lika stor procentandel trodde att de internationella hjälporganisationer som arbetade i regionen, inklusive FN:s organ, var lika korrupta. I rapporten görs följande tolkning:

Det verkar alltså för den genomsnittlige medborgaren som att korruptionen har brutit ner alla hinder och dikterar reglerna i livet. Det är ungefär som att säga att de tolkar livet $i$ korruptionstermer (UNDP 2002: 72).

Att människor "tolkar livet i korruptionstermer" kan rimligen sägas vara ett tecken på att det existerar ett djupt förankrat system av föreställningar om vad man kan förvänta sig av andra agenter. Ett system som enligt min uppfattning skapas av de historiskt etablerade institutioner under vilka agenterna lever. Om de här presenterade idéerna om korruption får stöd av sådana föreställningar och vi alltså ska tala om "interaktiv" rationalitet så får det konsekvenser för valet av antikorruptionsstrategi.

\section{Antikorruption som politik och forskningsobjekt - en kritik}

Ett samhälle som står inför uppgiften att ta itu med systemisk korruption och etablera en "god samhällsstyrning" måste ställa sig två huvudfrågor. För det första: Vad krävs det för typ av strukturella reformer för att minska korruptionen? Ett vanligt svar på den frågan är att man ska 
skapa nya, eller förändra redan existerande, rättsliga organ i syfte att påverka incitamentsstrukturerna för att ta emot eller ge mutor. Och för det andra: Vilka slags processer kan tänkas leda till framgång för sådana reformer? Det mesta av forskningen om korruption har intresserat sig för den första, strukturella, frågan medan den andra, processuella, frågan om förändring av agenters strategier och attityder i stor utsträckning har försummats.

Ekonomen William Easterly talar till exempel om två åtgärder som kan stoppa korruption: "Inrätta för det första kvalitetsinstitutioner ... Och driv för det andra en politik som minskar incitamenten för korruption" (Easterly 200I: 252). Rod Alence har lagt fram liknande förslag i en artikel, "Political Institutions and Developmental Governance in SubSaharan Africa" (2004), där han undersöker hur olika typer av politiska institutioner påverkar graden av korruption i trettioåtta afrikanska länder. Hans slutsats blir att en kombination av fria parlamentsval och institutionella mekanismer för kontroll av den verkställande makten minskar omfattningen av korruption. Genom att utöva liberal demokrati motverkar man alltså korruption. Broadman och Recanatini menar å sin sida att man för att åstadkomma förändring framför allt måste inrätta marknadsekonomiska institutioner som "tydliga och genomskinliga regler ... och en robust konkurrenspräglad miljö" (Broadman \& Recanatini 200I: 359).

Vad dessa exempel från litteraturen om antikorruption säger är att man, i enlighet med principal-agent-teorin, löser problemet med korruption genom att "fixa incitamenten". Det återstår bara ett problem, nämligen att skapandet av därför erforderliga institutioner i sig är ett problem för det kollektiva handlandet som inte är så lätt att lösa i ett samhälle dominerat av korrupta agenter (Falaschetti \& Miller 200I). Det existerar, som Ostrom (1998) påpekar, ett kollektivt handlingsproblem av andra ordningen. Varför skulle agenter som antingen drar vinning av korrupta praktiker eller förlorar på att avstå från korruption över huvud taget vara intresserade av att skapa sådana "effektiva" institutioner?

Listan över författare som pekar på det starka sambandet mellan institutioner som är karakteristiska för stabila demokratier med en välfungerande marknadsekonomi och en låg grad av korruption är faktiskt mycket lång. Men många av de råd om hur man ska sätta stopp för korruptionen 
som framförts i verk som ovanstående och av organisationer som FN:s utvecklingsprogram, Internationella valutafonden och Världsbanken förutsätter, som Hans Blomkvist har påpekat, att det finns tillgång på sådana administrativa praktiker och institutioner som korrupta länder är kända för att sakna (Blomkvist 20oI).

Författarna som utgår från det här perspektivet förklarar inte så mycket vad som ligger bakom korruption som de beskriver de institutionella systemens olika karaktärer i korrupta och icke-korrupta länder. Att lägga fram genomskinlighet, demokrati, oberoende rättsorgan eller "god samhällsstyrning" som lösningar på korruptionsproblem lämnar, i bästa fall, många viktiga frågor obesvarade. En mer grundläggande kritik som kan riktas mot dessa förslag till lösningar är att det i många fall bara skapas tautologier. Det kan formuleras i kausala termer som att beroende och oberoende variabler blir identiska. I stater som är välsignade med en självständig och hederlig rättsapparat, effektiva institutioner för bekämpning av korruption, effektiva redovisningssystem, lagar som garanterar informationsfrihet och självständiga medier och skydd för mänskliga rättigheter är det uppenbarligen så att dessa institutioner underlättar politiskt ansvarstagande och motverkar korruption. Men i stater som tvärtom lider av systemiskt korrupta strukturer är det sannolikt så att orsaksmekanismen går i andra riktningen, vilket innebär att det är korruptionen $\mathrm{i}$ just dessa typer av institutioner som hindrar utvecklingen mot ett demokratiskt styre (Diamond 2008). I sitt sökande efter generella teorier om orsaker till och lösningar på korruptionsproblem uppmärksammar många forskare inte den inbyggda institutionella trögheten (eller stigberoendet) hos korrupta system. Eller med Robert Harris ord:

precis som ett till övervägande del icke-korrupt system kommer att korrigera sig självt och ta itu med korrupta individer och de juridiska eller politiska brister som skapade förutsättningar för deras korruption, kommer ett till övervägande del korrupt system att korrigera sig självt och söka bevara sin korruption efter en upprensningsoperation (Harris 2003: 63).

Ett exempel på en sådan process är den aktuella utvecklingen i italiensk politik där situationen i vissa områden nu beskrivs som värre än före operationen "Rena händer", trots att det ända sedan början av 1990-talet har 
gjorts stora ansträngningar att utrota den politiska korruptionen (Della Porta \& Vannucci 2007). Claus Offe ställer frågan om vad det är som driver in länder i en ond cirkel med korrupta institutioner och "vilka motiv, värden och politiska krafter som faktiskt tvingar fram reformprojekt ... och vilka de incitament är som kan introducera incitament avsedda att kontrollera korruption eller forma om möjlighetsstrukturerna?” (Offe 2004: 91).

Och ska det skapas nya institutioner blir frågan om handling central. Det stora problemet med att inrätta opartiska och universella politiska institutioner är att de ska tjäna det "allmänna goda" och att intressebaserade aktörer inte har något skäl att bidra till skapandet av sådana (Bukovansky 2006; Falaschetti \& Miller 200I). Det verkar som att man har letat mer efter strukturer som samvarierar med en låg grad av korruption än efter agenter som kan bygga upp de institutioner som krävs för en "god samhällsstyrning". Om man ska göra sig en riktig bild av vad som kan bli en framgångsrik reformprocess måste man börja med att identifiera olika agenters roller och intressen. Till exempel är följande frågor viktiga: Vilka grupper kan tänkas motsätta sig reformer och hur ska man hantera detta motstånd? Vilka kan förväntas stödja förändring, vilka strategier kommer de att använda och hur drar man bäst in dem i kampen mot korruption?

Det finns inte heller mycket som talar för det av Tanzi (2000) och Alesina och Angeletos (2005) framlagda nyliberala argumentet att en stor statlig förvaltning leder till korruption. De två senare forskarnas slutsats att "en stor statlig sektor ökar korruptionen och räntesökandet" (2005: I8) får inte stöd av empirisk forskning (Gerring \& Thacker 2005; Hopkin \& Rodríguez-Pose 2007).

\section{Vad kan tänkas sätta stopp för korruption?}

De flesta forskare som vågar sig på att forska om korruption och presenterar sina idéer för politiker, studenter och kolleger från andra forskningsområden upplever följande: Efter att ha förklarat varför korruption är ett intressant och utmanande område för forskning och beskrivit hur korrupta praktiker fungerar och vilka (ödesdigra) konsekvenser de får på 
många områden ställs de inför frågan om "vad man ska göra”. Många praktiskt verksamma, till exempel de som arbetar inom den internationella biståndsindustrin, tycks ha en föreställning om att det finns vissa "magiska nycklar" som kan sätta i gång en inkrementell förändringsprocess som steg för steg leder ett korrupt samhälle bort från systemisk korruption och etablerar vad som har betecknats som good governance ("god samhällsstyrning") (B. Smith 2007) eller quality of government ("god myndighetsutövning") (Rothstein \& Teorell 2008). Det verkar som att de flesta statsvetare nu för tiden är benägna att uppfatta social förändring på ett sådant stigberoende, inkrementellt sätt. I vilket tillstånd ett samhälle än befinner sig så har det uppstått i ett "kritiskt” eller "formativt" ögonblick långt baka i tiden. En mindre institutionell förändring har satt i gång ett slags "återkopplingsmekanism" eller "autokorrelation" som leder till en god (eller ond) kausal cirkulation mellan två eller flera variabler så att de förstärker varandra över tiden och får samhället att följa en "utvald stig". Som Paul Pierson uttrycker det: "i och med att återkopplingsloopar får en central betydelse för den process som följer efter ett kritiskt ögonblick blir det omöjligt att urskilja tydliga orsaker och verkningar; i stället förstärker en rad faktorer varandra” (Pierson 2004: 95). Han säger också:

Några inledande steg i en viss riktning kan stimulera till ytterligare rörelse längs samma stig. Stigar som inte valts kan med tiden bli alltmer avlägsna, alltmer ouppnåeliga alternativ (2004: 64).

Med ett sådant sätt att tänka inriktas analysen av hur man ska stoppa korruption och etablera en "god myndighetsutövning" på att hitta dessa "inledande steg" som fungerar som en "magisk nyckel" som kan få ett land att börja följa en stig som leder bort från systemisk korruption. Ett typiskt exempel på ett sådant tänkande utgör en rapport från Världsbanken om hur man kan bekämpa korruption. Utmaningen är, enligt rapporten, att hitta "en lämplig ingångspunkt för antikorruptionsåtgärder". Rapporten säger vidare att "det är viktigt att börja i en punkt där målen är möjliga att nå och påtagliga resultat kan realiseras inom en tidsram som skapar stöd för ytterligare reformer. Små framgångar kan få den allmänna och den officiella opinionen att svänga” (Världsbanken 2000: 75). 
På liknande sätt sägs i FN:s Global Programme against Corruption den bästa strategin vara "en långsiktig process varigenom korrupta värderingar och praktiker gradvis identifieras och elimineras" (FN 2004: 17). Om man alltså bara kunde hitta den magiska nyckeln ("ingångspunkten”) skulle man kunna ge policyskaparna råd i det här viktiga ämnet. Om stora skillnader börjar med små förändringar måste vi hitta fram till dessa små förändringar.

Enligt den rumänska statsvetaren Alina Mungiu-Pippidi finns det, trots stora ansträngningar från internationella givarorganisationer att driva en antikorruptionspolitik, inte så många framgångssagor att berätta. Hon säger varnande att de många verkningslösa kampanjerna "gör väljarna ytterst cyniska och hotar att undergräva den allmänna tilliten i de framväxande demokratierna” (Mungiu-Pippidi 2006: 82). För henne är problemet i ett land som Rumänien att kampanjerna inte tar hänsyn till att korruptionen har sina rötter i en partikularistisk politisk kultur, i vilken nästan alla offentliga nyttigheter distribueras "på en icke-universalistisk basis som speglar den skeva maktfördelningen" i landet. Människor "räknar inte med att bli rättvist behandlade av staten; vad de däremot räknar med är att alla med samma samhällsställning får samma behandling”. Risken är därför att de antikorruptionsåtgärder som sätts i verket med stöd av internationella organisationer (till exempel ett nytt antikorruptionsorgan) kommer att tas över av mer eller mindre korrupta nätverk.

I en sådan politisk kultur, där det är förbindelser, förmågan att ge mutor eller deltagande i olika klientilistiska nätverk som bestämmer vad man får ut från den politiska sektorn, kommer etablerandet av några få välvilliga "principaler" i "västerländsk stil" inte att hjälpa mot korruption eftersom de också snart blir präglade av rådande bruk och missbruk (Doig, Watt \& Williams 2007). Inte ens den berömda svenska antikorruptionsinstitutionen ombudsmannen, som har kopierats i så många framväxande demokratier, har enligt Mungiu-Pippidi "varit särskilt framgångsrik eftersom den historiska process som gynnade universalism på bekostnad av partikularism i de skandinaviska länderna har lyst med sin frånvaro" (2006: 96).

Denna begreppsdistinktion mellan en universell och en partikularistisk politisk kultur liknar vad North, Wallis och Weingast i en nyutkom- 
men bok har kallat "samhällsordning med begränsad tillgång" (limited access social order) respektive "samhällsordning med fri tillgång" (open access social order). Den förra samhällsordningen karakteriseras av "privilegierad tillgång till värdefulla rättigheter och verksamheter" och "bygger på en benägenhet hos människan att skapa personliga relationer" (North, Wallis \& Weingast 2009). De exemplifierar med en aristokratisk-feodal stat, en klientkapitalistisk autokrati i ett utvecklingsland eller en kommuniststat i sovjetisk stil. Den senare samhällsordningen, som huvudsakligen existerar i de utvecklade OECD-länderna, utmärks däremot av fri tillgång till politiska och ekonomiska arenor där det råder konkurrens och man ingår specifika men opersonliga avtal (2009: 40). Det är denna weberianska "opersonliga" form av styrning och ingående av avtal som kan karakteriseras som den grundläggande normen i en "universell" samhällsordning/politisk kultur "med fri tillgång".

Både North och hans kolleger och Mungiu-Pippidi argumenterar övertygande för att korruption och liknande praktiker är rotade i djupt förankrade föreställningar om hur man lämpligen genomför utbyten i ett samhälle. Följaktligen måste hela den samhälleliga ordningen/ politiska kulturen förskjutas från ett "partikularistiskt" jämviktstillstånd med "begränsad tillgång" till ett jämviktstillstånd präglat av "opersonliga" och/eller "universella" former av utbyte för att det ska bli stopp på korruptionen och etableras en "god samhällsstyrning". Ett centralt argument i båda artiklarna är att en specifik typ av institution (till exempel rättssystemet eller en konstitution) kommer att fylla ytterst olika funktioner i olika miljöer. Att ta små steg genom att inrätta en specifik institution som en ombudsman eller en antikorruptionskommission i syfte att förändra en samhällsordning/politisk kultur är därför med all sannolikhet meningslöst. Som North och hans kolleger skriver: "Historien tycks inte ... erbjuda något större utbud av samhällen som gradvis går över från gamla till nya politiska och ekonomiska institutioner" (North m.fl. 2009: 33). Tyvärr vet vi inte särskilt mycket om hur en sådan övergång kan genomföras. Hur man etablerar universella, opersonliga och opartiska politiska institutioner som skapar förutsättningar för "trovärdiga förpliktelser" mellan konkurrerande aktörer förblir något av ett mysterium, inte minst ur ett rational choice-perspektiv (Falaschetti \& 
Miller 200I; Hechter 1992; Lichbach 1997). Eller som det formuleras i en annan aktuell handbok i ekonomi: det gåtfulla är att sådana "effektiva” institutioner "verkar i ett fătal utvecklade länder och bara i modern tid. $\mathrm{Vi}$ vet förvånansvärt lite om den institutionella utveckling som ledde fram till dessa moderna framgångar" (Greif 2005: 773).

Problemet begränsar sig inte till förändringar i formella institutioner utan gäller även för de informella institutionernas del. Det är naturligtvis svårt att avslöja hur sådana institutioner fungerar, men en ledtråd kan man finna i den starka korrelationen mellan å ena sidan höga nivåer av social tillit och förtroende för rättssystemet och å andra sidan låga nivåer av korruption. Det diskuteras mycket om hur man ska tolka människors svar i undersökningar av tillit och förtroende, men jag håller med Delhey och Newton om att när människor besvarar frågan om de tror att "man kan lita på de flesta andra människor" så kan det tolkas som deras bedömning av den moraliska standarden i det samhälle de lever i, det vill säga kvaliteten på de informella institutionerna i deras samhälle (Delhey \& Newton 2004). Om de flesta i ett samhälle tror att de flesta andra människor i deras samhälle kommer att uppträda på ett hederligt sätt kommer, i enlighet med den ovan beskrivna "interaktiva rationalitetens" logik, den enskilda agent som inleder en transaktion med en för henne främmande människa att ha mindre skäl att känna rädsla för att bli föremål för ett bedrägligt eller exploaterande beteende. Samarbete mellan människor som inte känner varandra personligen kommer följaktligen att vara vanligare i ett samhälle med en hög nivå av social tilllit. Resultatet av social och ekonomisk interaktion är alltså beroende av hur "verklighetskontexten" har konstruerat de "ömsesidiga förväntningarna", till exempel förväntningarna om huruvida man lita på de andra spelarna eller ej.

Konsekvenserna av den här analysen är så här långt tämligen negativa. För det första får korruption stöd av en hel rad historiskt rotade formella och informella institutioner i ett samhälle. För det andra är det inte så lätt att förändra vare sig de formella eller de informella institutionerna eftersom de utgör "självförstärkande" jämviktstillstånd. Om en agent försöker reformera en enstaka eller några få institutioner i en korrupt politisk kultur präglad av partikularism och begränsad tillgång 
kommer det troligen att misslyckas eftersom de nya institutionerna tas över av de korrupta/klientilistiska nätverken och själva präglas av sådana praktiker, vilket i sin tur kommer att förstärka cynismen bland befolkningen och tjäna till att avlegitimera framtida försök att öka de offentliga institutionernas kvalitet (jfr Doig m.fl. 2007).

\section{I8oo-talets Sverige - från partikularism och korruption till god samhällsstyrning}

Sverige och de andra nordiska länderna tycks utgöra ett mysterium i den här diskussionen. $\AA$ ena sidan karakteriseras de av de flesta egenskaper som enligt traditionell ekonomisk teori skulle göra dem till oförbätterligt korrupta (Alesina \& Angeletos 2005). De har till exempel mycket stora offentliga sektorer, interventionistiska stater och väldiga byråkratier med betydande makt över många olika typer av regleringar. Men å andra sidan visar de vanligaste måtten på graden av korruption raka motsatsen, nämligen att de har de lägsta nivåerna av korruption (Hopkin \& RodríguezPose 2007; Uslaner 2008). Men i strid med vad man i allmänhet tror var de nordiska länderna i början av I80o-talet i grunden klientilistiska och även i viss utsträckning korrupta (Frisk Jensen 2008; Rothstein 1998). Som kommer att visas nedan förändrades detta dramatiskt under århundradets senare del. Om man ser korruption som ett universellt, och inte ett specifikt kulturellt, problem får frågan om hur i8oo-talets Sverige lyckades besegra korruptionen stor relevans för många utvecklingsländer.

Det var i början av I8oo-talet vanligt inom den svenska statsförvaltningen att en och samma ämbetsman innehade fem, sex heltidstjänster, att personliga kontakter med hovet var viktigare än opersonliga lagar, att adelsmän hade företräde till tjänster och laglydnad sågs som något mer eller mindre frivilligt. Det så kallade ackordssystemet gjorde det möjligt för ämbetsmän som ville göra karriär att köpa ett högre ämbete genom att betala innehavaren av det ett ackord i form av en viss summa pengar (Frohnert 1993: 287). Denne kunde i sin tur använda pengarna för att köpa sig ett nytt, högre ämbete eller använda dem som sin pension. Systemet fungerade delvis för att det inte fanns något pensionssystem för ämbetsmän, men också därför att det saknades åldersgränser för när en 
ämbetsman kunde tvingas lämna sin post. Varken allvarlig sjukdom eller annat hinder för utförande av plikterna var giltiga skäl till avskedande av en ämbetsman. Detta var en konsekvens av att offentliga ämbeten betraktades som innehavarens egendom i stil med en jordförläning som tillerkänns den som betygar kungen sin lojalitet. Under I700- och I80o-talen utfärdades dock en rad förbud mot köpandet av tjänster. Det faktum att de knappt fick några effekter alls ger en viss insikt i lagstiftningssystemet i ett samhälle med begränsad tillgång (Myrberg 1922).

Ett annat exempel är utbildning och färdigheter. I en byråkrati av weberiansk typ måste ämbetsmän ha en viss grad av specifik kunskap om landets rätts- och förvaltningssystem, och rekryteringen bör vara meritokratisk. Men i det tidiga I80o-talets Sverige var det sällan fallet. Sten Lindroth beskriver hur den juridiska utbildningen vid Uppsala universitet satt fast i ett intellektuellt och organisatoriskt moras som varade in på I900-talet (Lindroth 1976). Situationen var densamma vid Lunds universitet (Gierow 197I: 224). Till exempel riktade kanslikollegium 1797 en skrivelse till prokansler, rektor och konsistorium som kritiserade det faktum att man

stundom måst erfara, att de ynglingar, vilka söka inträde uti kansliverket, icke ägt den kunskap uti språk och vetenskaper, som för ett kansliämne betarvas, oaktat de varit med akademiska betyg försedda (I971: 237).

Detta gällde inte minst de så kallade ämbetsexamina som var främsta rekryteringsinstrumentet vid anställning i den centrala statsförvaltningen. I859 skriver juridikprofessorn Knut Olivecrona följande i sin historiska redogörelse för den juridiska utbildningen vid Uppsala universitet $1785-1823$ :

Under den långa tid då Hernberg, Lundström och Drissel beklädde den maktpåliggande juris patrii-professionen sjönko de rent juridiska studierna till det yttersta förfallet. Den s.k. Hofrättsexamen blef en obetydlighet; juris candidatexamen absolverades med den allra största lätthet och i Romerska Rätten erfordrades ej ens den allra ytligaste kunskap (Olivecrona 1859: I4).

Den så kallade kameralexamen, en av de ovan nämnda ämbetsexamina som gav tillträde till de allra högsta positionerna i statsapparaten betrak- 
tades av den berömda så kallade snillekommittén (en kommitté av kulturpersonligheter som staten utsett för att granska utbildningssystemet) i deras rapport från 1828 som rena parodin (Lindroth 1976: 165). Per Frohnerts noggranna historiska studie av den lokala svenska skatteförvaltningen visar också att det inte ställdes några formella utbildningskrav på lokala civila ämbetsmän under I700-talet och i början av I80o-talet. Kronan belönade inte akademiska grader när sådana lokala poster skulle tillsättas. Skälet tycks ha varit att reglerna för arbetet med skatteuppbörden skiftade så mycket mellan olika län (Frohnert 1993: 165). Det visar att generella regler inte spelade någon större roll ens på ett så centralt område som beskattning.

I sitt svar på kanslikollegiets kritik av universitetsutbildningen förklarade universitetskanslern vid Lunds universitet att en viktig faktor som låg bakom den ogynnsamma situationen var att studenterna var så unga, under tjugo år, och förståeligt nog inte mottagliga för den utbildning som de erbjöds. Det var i sin tur en konsekvens av det faktum att

föräldrar och anhöriga antingen av fåfänga eller bristande kännedom, hava för huvudändamål att blott påskynda deras barns tidiga inträde på tjänstevägen utan att låta dem vid akademien mogna i förstånd och kunskaper, och då ynglingar, sig själv lämnade, bygga deras hopp om framtida fortkomst mera på förmögenhet och gynnande förbindelser, än på en genom förvärvade nödiga insikter behörigen grundlagd skicklighet (Gierow I97I: 238).

Eftersom principen om anciennitet var avgörande för befordran blev det viktigt att få in sin avkomma vid ett ämbetsverk så tidigt som möjligt, kanske redan i tvåårsåldern (fast naturligtvis utan krav på arbete eller ersättning).

Så småningom infördes det åldersgräns och minimikrav på studietid för anställning i ett ämbetsverk. Men juridikprofessorn Holmbergsson vid Lunds universitet menade i en skrivelse I83I att det inte var tillräckligt. Vad man i stället borde göra var att förändra befordringssystemet så att det blev faktiska meriter och antalet tjänsteår som blev utslagsgivande för ämbetsmannakarriären (Gierow I97I: 252).

Till detta kom att lönesystemet var långtifrån universellt och opersonligt under I80o-talets första hälft. Även om ersättning in natura var det 
vanligaste existerade det också pekuniära ersättningar. Extra förmåner och avgifter för till arbetet knutna tjänster, eller mutor enligt dagens normer, var flitigt förekommande (Westerhult 1965). Ämbetsmannen hade också ofta inkomster från jord och egendomar som tillhörde ämbetet. Särskilt inom den högre förvaltningen och universiteten gjordes det utnämningar till ämbeten utan att det fanns medel för ersättning eller krävdes något arbete på posten (Gierow I97I: 25-27). Medan på lägre förvaltningsnivåer "lönerna ... inom samma tjänstegrad [var] så växlande att åtskilliga av de bäst avlönade hade dubbelt så hög avlöning som sina sämst lottade kolleger" (Westerhult 1965: 107). En studie av lokala ämbetsmän under I700talet visar att "en stor andel av lönen var ... knuten till enskilda bönder som var tvungna att leverera spannmål, pengar eller andra varor" (Frohnert 1993: 367). I ett brev till Kunglig Majestät I8II påpekade Kammarkollegiet att ämbetsmännens ersättningar hade sjunkit så lågt att många av dem hade tvingats att ta anställningar i andra verk och organ (samtidigt som de naturligtvis behöll sina gamla poster), och att detta kraftigt hade försvårat och fördröjt arbetet i centrala delar av den svenska statsförvaltningen (Edén, Berglöf \& Schalling 194I: 278). Det var mycket vanligt att en enskild ämbetsman innehade flera ämbeten på det sättet, och systemet förbjöds inte förrän I879. En statlig kommitté förklarade i ett betänkande 1822 att beroende på de låga lönerna var de ämbetsmän som inte hade privata förmögenheter tvungna att antingen leta efter andra poster eller försörja sig genom egen affärsverksamhet (Rothstein 1998). Gunnar Heckscher sammanfattade i sin epokgörande bok om svensk statsförvaltning (Heckscher 1952: 19) den centrala förvaltningen i början av ı8ootalet som "tämligen försumpad".

Förändringen i riktning mot ett weberianskt förvaltningssystem ägde rum mellan I860 och I875 och var både "icke-inkrementell” och dramatisk. Och vad som var viktigast: hela föreställningen om vad det innebar att vara ämbetsman förändrades. En offentlig post betraktades inte längre som ett slags förläning som ”ägaren” kunde utnyttja efter eget skön för att dra in inkomster, utan var ett heltidsjobb med fast lön som man fick i öppen, meritokratisk konkurrens och som utfördes enligt en samling regler och lagar. Historikern och riksarkivarien Emil Hildebrand hävdade i sin bok om den svenska statsförfattningen att "den gamla uppfattningen 
och behandlingen af ämbete som egendom började arbetas bort" (I896: 653). Korruption, klientilism och liknande praktiker förekom naturligtvis fortfarande i viss utsträckning, men de betraktades inte längre som "standardprocedurer". Det kanske mest talande belägget för detta är August Strindbergs ytterst livfulla och negativa beskrivning i Röda rummet (I879) av ett prototypiskt ämbetsverk, det fiktiva Kollegiet för Utbetalande av Ämbetsmännens löner. Byråkraterna beskrevs som ytterst konservativa, lata och ineffektiva, men inte korrupta. Hade ämbetsmän då i allmänhet betraktats som korrupta hade radikalen Strindberg rimligen lagt till detta i listan över försyndelser. Men det gjorde han inte, och skälet till det var antagligen att det inte skulle ha väckt anklang hos allmänna opinionen. Det utmärkande för den här perioden är i vilket fall som helst de många och dramatiska institutionella förändringar i riktning mot "god samhällsstyrning" som ägde rum. Här följer bara en kortare förteckning:

I84I-62 Inrättande av statliga verk för genomförande av stora investeringar i infrastruktur (Kongl. Styrelsen för allmänna wäg- och wattenbyggnader I84I, Kongl. Elecktriska Telegraf-Werket I853, Styrelsen öfver statens järnvägsbyggnader I863). Därmed erhålls en helt ny kader av mer professionellt utbildade ämbetsmän som tillsätts efter meriter.

I842-62 Allmän folkskola införs och genomdrivs under I860-talet med hjälp av statliga folkskoleinspektörer.

I845 Regeringens rätt att inställa utgivningen av en tidning ("indragningsmakten") avskaffas, vilket från och med i850-talet gör det möjligt för pressen att föra en debatt om offentliga angelägenheter.

I845 Den sista formella företrädesrätten för adelsmän till högre statliga ämbeten avskaffas. I praktiken bevarar adeln sina privilegier fram till mitten av I86o-talet.

I845 Kvinnor och män får lika arvsrätt.

I846 Skråväsendet avskaffas.

I848 Aktiebolagslag antas.

I855-60 Stor revidering av lönesystemet i den svenska statsförvaltningen i "weberiansk" riktning.

I860 Rätt att lämna Svenska kyrkan, men bara för att gå in i annat kristet samfund.

I862 Utfärdande av förordningar gällande kommunal styrelse och landsting varigenom kommunerna erkändes som självständiga juridiska personer.

I862 Ny strafflag som inkluderar ämbetsbrott. 
I863 Nya regler för universitetsutbildning som innebär högre examenskrav.

I864 Näringsfrihet införs.

I866 De fyra stånden avskaffas och det inrättas en "modern" tvåkammarriksdag.

ı868 Riksdagen beslutar att avskaffa direkta betalningar för tjänster till enskilda ämbetsmän. De avgifter som medborgarna betalar för olika tjänster ska inte längre tillhöra den enskilde ämbetsmannen utan vara statlig egendom.

I869 Riksdagen beslutar att skatt ska betalas i penningar och inte in natura.

I870 Judar får fulla medborgerliga rättigheter så att de till exempel kan sitta i riksdagen och inneha statliga ämbeten.

I876 Större omorganisering av den statliga förvaltningen från kollegialt beslutsfattande (domstolsmodellen) till det moderna byråsystemet med hierarkisk struktur.

I878 Avskaffande av ackordssystemet och införande av ett fungerande pensionssystem för ämbetsmän. ${ }^{3}$

En blick på denna lista över institutionella förändringar avslöjar tre saker. De är, för det första, starkt koncentrerade i tiden med I860-talet som kulmen, även om några av dem inleddes redan under I840-talet. Man kan, för det andra, tala om en icke-inkrementell big bang-förändring i riktning mot vad Mungiu-Pippidi (2006) har kallat en "universalistisk" politisk kultur och North med flera (2009) har betecknat som en "samhällsordning med fri tillgång". Nästan alla stora politiska, sociala och ekonomiska formella institutioner förändrades under en relativt kort tidsperiod med I860-talet som det centrala decenniet. För historikern Sten Carlsson är åren mellan I856 och I886 en "liberal högkonjunktur" (citerad i Nilsson 200I: 258). Ur mitt teoretiska perspektiv är det viktigt att understryka att det sannolika resultatet av en massiv institutionell förändring som denna är att var individen än tittade så såg hon stora förändringar, inte bara på några få områden utan "överallt". Det borde rimligen få henne att grundligt åter överväga frågorna om "hur man ska spela" och "vad man ska förvänta sig”.

Det tredje man lägger märke till är att få av dessa förändringar var riktade direkt mot korruptionen. I stället användes mer indirekta metoder som kom att gälla hela det politiska systemet i landet. Det handlade alltså inte om direkta angrepp på korruption och klientilism, utan om

3. Tack till Maria Cavallin Ajmer för de flesta av uppgifterna här. 
att förändra den politiska kulturen, om att förvandla en partikularistisk politikförståelse till en universalistisk. ${ }^{4}$

Som tidigare konstaterats borde inte bara formella utan även informella institutioner (som allmän tillit) vara viktiga drivkrafter bakom denna utveckling. Förändringar bakåt i tiden av informella institutioner är genom själva sin natur svårare att spåra, men på ett viktigt område finns det vissa indikatorer på att den här perioden också såg förändringar i det avseendet. I80o-talets mitt var i Sverige också en period då frivilligorganisationer dramatiskt ökade i antal och vidgade sin verksamhet. Det är förvisso sant att det inte är alla frivilligorganisationer som tjänar till att öka den sociala tilliten eller försöker skapa oväldiga/universella statliga institutioner (Armony 2004; Berman 1997). Men det viktiga med de många institutioner som faktiskt bildades var, för det första, att de inte var slutna som skråna en gång hade varit utan var öppna för alla samhällsklasser. För det andra lades det i deras målsättningar, regler och stadgar stor vikt vid "det allmänna bästa", "det gemensamma" och "att tjäna nationen" (Jansson 1985: 24I). Enligt den grundligaste historiska studien av den här processen var detta fenomen så påfallande att man kan tala om en "metaideologi" (Jansson 1985: 242) och som ett sätt att vinna respekt (Pettersson 1995). Detta starka stöd för de "fria associationerna" kom också från viktiga medlemmar av den nya kapitalistklassen, inte minst från grundaren av Wallenbergdynastin (Nilsson 200I: I23).

Här är inte platsen för att göra en fullständig komparativ studie av de politiska förändringar som tjänade till att utplåna korruption i andra västländer under samma period. Men det finns tydliga tecken på att sådana ägde rum i flera länder. Danmark visar upp en liknande stor institutionell förändring mellan I840 och I860 "då korruptionen nästan utplånades" (Frisk Jensen 2008: 29I). I USA genomgick en korrupt politisk kultur en omstöpning under den "progressiva rörelsen" som inleddes i slutet av I8oo-talet. Enligt Arnold var rörelsen inte bara intresserad av att öka det politiska styrets effektivitet, utan dess mål var ingenting mindre än att

4. Militärhistoriskt intresserade läsare ser säkert likheten med Basil Liddell Harts berömda "indirekta strategi": "För att besegra fienden måste man först rubba hans jämvikt, vilket inte sker genom huvudattacken utan måste göras innan huvudattacken kan lyckas." 
åstadkomma en "moralisk rening". Den hade "total framgång" i sin strävan att utplåna korruption och patronage $\mathrm{i}$ den federala regeringen inte för att den koncentrerade sina ansträngningar på korruptionen utan för att den fogade in "kriget mot korruption" i en vidare ram där det handlade om att förändra hela den politiska kulturen. Särskilt Civil Service Reform League lyckades förändra "den allmänna föreställningen om vad som borde vara kärnan i amerikansk politik och federalt styre" (Arnold 2003: 205f). Ett tredje exempel är den berömda Northcote-Trevelyanrapporten som kom I853 och argumenterade för införandet av ett meritokratiskt system för rekrytering till den brittiska statsförvaltningen. Inte heller den rapporten hade som direkt mål att utplåna korruptionen utan anlade ett bredare universalistiskt perspektiv på statsförvaltningen som en del av den brittiska politiska kulturen (Chapman \& Greenaway 1980; Harling 1996). Ett fjärde exempel på en sådan big bang-förändring av hela den politiska kulturen är den "revolution uppifrån" som ägde rum i Bayern i början av I90o-talet när inrikesministern Maximilian von Montgelas inte bara skapade en meritokratisk och regelstyrd förvaltning utan även moderniserade och sekulariserade hela det bayerska samhället på ett sätt som liknade utvecklingen i Sverige (Weis 2005).

\section{Antikorruption. Big bang-ansatsen}

Samhällsvetare bygger på endera av två helt skilda föreställningar när de söker förstå mänskligt handlande. Antingen är agenterna mer eller mindre "dopade" av sin kultur och historia och alltså strukturellt och/ eller historiskt bestämda att handla som de gör, eller så är de nyttomaximerande rationella agenter som gör ständiga kostnads-nyttoanalyser av de olika incitamentssystem som de möter. Men dessa föreställningar kan inte förklara förändring eftersom vi inte har några goda teorier om hur kultur eller incitamentsframkallande institutioner förändras. Båda ger i själva verket högst osannolika beskrivningar av hur människor avgör "hur de ska spela" eller "vad de kan förvänta sig”. En mer realistisk bild av hur man kan förstå mänskligt handlande kommer från Peyton Youngs arbeten inom evolutionär spelteori. Det slaget av teori är intressant för antikorruptionsforskning eftersom det lägger fokus inte på ”engångs- 
interaktioner” utan på en (oändlig) rad av stora och små strategiska interaktioner mellan $n$ personer. Med detta följer en mer realistisk föreställning om mänskligt handlande som jag tror är användbar: "Agenter är inte helt rationella och fullständigt informerade om den värld som de lever i”, utan "bygger sina beslut på fragmentarisk information” och "gör sig ofullständiga föreställningar om den process som de är indragna i”. Men Peyton Young är förvisso inte någon (postmodernistisk) kulturteoretiker; människor är inte "helt irrationella", utan "anpassar sitt beteende efter vad de tror att andra agenter tänker göra, och dessa förväntningar skapas endogent av information om vad andra agenter har gjort i det förflutna” (Young 1998: 6). Om vi vill förstå varför människor skulle förändra sitt beteende och bli mindre korrupta är det med andra ord inte till någon större hjälp att studera deras preferenser, normer och attityder (Goudie \& Stasavage 1998). I en alltigenom korrupt miljö kommer även människor som tycker att korruption är moraliskt fel sannolikt att ägna sig åt det eftersom de inte ser någon poäng med att handla annorlunda (Della Porta \& Vannucci 1999). Det avgörande blir vilka föreställningar de gör sig om andra agenters föreställningar eller, med andra ord, vilka föreställningar de har om hur deras värld fungerar.

Detta får vissa konsekvenser i ett policyperspektiv. För det första pekar den här teorin inte ut vissa institutioner som viktigare än andra att förändra. Domstolarna är inte viktigare än den offentliga förvaltningen, de politiskt valda ledarna, det civila samhället eller massmedierna. Skälet till det är att om man bara reformerar en institution kommer korruptionen sannolikt att krypa över till en annan. Agenter i till exempel ett mäktigt korrupt nätverk måste snarare inse att varhelst de vänder sig så är det fråga om "ett nytt spel i stan”. För det andra måste (nästan) allt förändras, och det bör ske så samtidigt som möjligt. Man kan uppfatta det som ett behov att nå en schellingsk "tippunkt" för att komma fram till en ny jämvikt (Schelling 1996). Om man i kampen mot korruption begränsar sig till mindre åtgärder ("ingångspunkter") kommer man inte att övertyga tillräckligt med agenter om att det inte längre är ett praktiskt alternativ att fortsätta med korrupta praktiker, och systemet kommer sannolikt inte att nå den viktiga "tippunkten" utan återfalla i sina gamla systemiska korruptionspraktiker. Enkelt uttryckt: gör inget litet. Eller som 
Larry Diamond, en av de mest aktade demokratiseringsforskarna, har formulerat det: "Endemisk korruption är inte någon brist som kan rättas till med en technical fix eller politisk kraftansträngning. Det är så systemet fungerar, och det är djupt inbäddat i det politiska och sociala livets normer och förväntningar. För att reducera det till mindre destruktiva nivåer - och hålla kvar det där - krävs det revolutionerande förändringar i institutioner” (Diamond 2007: II9). För det tredje får åtgärder som riktas direkt mot korrupta praktiker förmodligen betydelse, men det tycks vara ännu viktigare att införa nya institutionella praktiker som fungerar som ett mer indirekt sätt att angripa problemet med korruption. Som det svenska fallet (och andra fall) visade ovan bör sådana indirekta åtgärder försöka inprägla universalism och opartiskhet som grundläggande normer för hur staten bör verka.

Om denna big bang-ansats kan få stöd av mer empirisk forskning blir rådet till exempelvis internationella givare eller ledare i korrupta samhällen som vill välja den "goda samhällsstyrningens" dagordning följande: Om man bara har begränsade resurser är det bättre att spara dem tills man kan samla sig för en big bang-förändring. Annars kan man hamna i en ännu värre situation eftersom de antikorruptionskrafter man har satt i gång inte bekämpar (eller anses bekämpa) utan stöder korruption, vilket kommer att sprida cyniska föreställningar bland människor om "vad man ska förvänta sig” och göra det ännu svårare att förändra deras djupt förankrade föreställningar om "hur man ska spela”.

\section{Översättning: Sven-Erik Torhell}

\section{Referenser}

Aidt, T. (2003). "Economic Analysis of Corruption: A Survey". The Economic Journal, II3 (november), F632-F652. DoI: http://dx.doi.org/I0.I046/j.0013-0133.2003.0017I.x

Alence, R. (2004). "Political Institutions and Developmental Governance in SubSaharan Africa". Journal of Modern African Studies, 42 (2), I63-187. DOI: http://dx.doi.org/IO.IOI7/Soo22278Xo4000084

Alesina, A. \& Angeletos, G.-M. (2005). "Corruption, Inequality, and Fairness". Journal of Monetary Economics, 52 (7), I227-I244. DOI: http://dx.doi.org/IO.IOI6/j.jmoneco.2005.05.003 
Armony, A. C. (2004). The Dubious Link. Civic Engagement and Democratization. Stanford: Stanford University Press.

Arnold, P. E. (2003). "Democracy and Corruption in the igth Century United States". I: S. Tiihonen (red.), History of Corruption in Central Government (s. 197-212). Amsterdam: IOS Press.

Aumann, R. J. \& Dreze, J. H. (2005). When All is Said and Done, How Should You Play and What Should You Expect? (Discussion paper 387, mars 2005). Jerusalem: Center for the Study of Rationality, Hebrew University.

Bardhan, P. (1997). "Corruption and Development: A Review of the Issues". Journal of Economic Literature, 35 (3), I320-I346.

Berman, S. (1997). "Civil Society and the Collapse of the Weimar Republic". World Politics, 49 (3), 4OI-429. DoI: http://dx.doi.org/IO.I353/wp.1997.0008

Blomkvist, H. (200I). "Stat och förvaltning i u-länder”. I: B. Rothstein (red.), Politik som organisation (3 uppl.). Stockholm: SNS.

Broadman, H. G. \& Recanatini, F. (200I). "Seeds of Corruption: Do Market Institutions Matter?". Moct-Most, II (4), 359-392.

Bukovansky, M. (2006). "The Hollowness of Anti-corruption Discourse”. Review of International Political Economy, I3 (2), I8I-209. DoI: http://dx.doi.org/Io.I080/09692290600625413

Chapman, R. A. \& Greenaway, J. R. (1980). The Dynamics of Administrative Reform. London: Croom Helm.

Cupit, G. (2000). When Does Justice Require Impartiality? London: Political Studies Association - UK soth Annual Conference, IO-I3 april.

Delhey, J. \& Newton, K. (2004). Social Trust. Global Pattern or Nordic Exceptionalism (Discussion paper). Berlin: Wissenschaftszentrum Berlin für Socialforschung.

Della Porta, D. \& Vannucci, A. (1999). Corrupt Exchanges. Actors, Resources, and Mechanisms of Political Corruption. New York: Aldine de Gruyter.

Della Porta, D. \& Vannucci, A. (2007). "Corruption and Anti-corruption: The Political Defeat of 'Clean Hands' in Italy". West European Politics, 30 (4), 830-853. DoI: http://dx.doi.org/Io.Io8o/oI402380701500322

Diamond, L. (2007). "A Quarter-Century of Promoting Democracy". Journal of Democracy, I8 (4), II8-I2O.

Diamond, L. (2008). "The Democratic Rollback: The Resurgence of the Predatory State". Foreign Affairs, 87 (2).

Dinesen, P. T. (2006). Social tillid, civilsamfund og institutioner. En empirisk analyse af årsager til social tillid i Europa. Avhandling. Aarhus: Aarhus Universitet.

Doig, A., Watt, D. \& Williams, R. (2007). ”Why Do Developing Country Anti-corruption Commissions Fail To Deal with Corruption? Understanding the Three Dilemmas of Organisational Development, Performance Expectation, and Donor and Government Cycles". Public Administration and Development, 27 (3), 25I-259. DOI: http://dx.doi.org/Io.IOO2/pad.452 
Dryzek, J. S., Phillips, A. \& Honig, B. (2006). The Oxford Handbook of Political Theory. Oxford: Oxford University Press.

Easterly, W. (200I). The Elusive Quest for Growth. Cambridge: MIT Press.

Edén, N., Berglöf, L. \& Schalling, E. (I94I). Kammarkollegiets historia. Stockholm: Isaac Marcus.

Falaschetti, D. \& Miller, G. (200I). "Constraining Leviathan: Moral Hazard and Credible Commitment in Constitutional Design". Journal of Theoretical Politics, I3 (4), 389-4II.

DOI: http://dx.doi.org/IO.II77/0951692801013004003

FN (2004). The Global Programme against Corruption. United Nations Anti-Corruption Toolkit (3 uppl.). Wien: United Nations Office on Drugs and Crime.

Frisk Jensen, M. (2008). Korruption og embedsetik. Danske embedsmands korruption i perioden I80o til I886. Avhandling. Aalborg: Aalborg Universitet.

Frohnert, P. (1993). Kronans skatter och bondens bröd. Den lokala förvaltningen och bönderna i Sverige I7I9-I775. Lund: Rättshistoriskt bibliotek.

Gerring, J. \& Thacker, S. C. (2005). "Do Neoliberal Policies Deter Political Corruption”. International Organization, 59 (I), 233-254.

DOI: http://dx.doi.org/Io.IOI7/Soo20818305050083

Gierow, K. (197I). Lunds universitets historia, III, I790-I867. Lund: Gleerup.

Goudie, A. W. \& Stasavage, D. (1998). "A Framework for the Analysis of Corruption”. Crime, Law \& Social Change, 29 (2-3), $113-159$.

Greif, A. (2005). "Commitment, Coercion, and Markets: The Nature and Dynamics of Institutions Supporting Exchange”. I: C. Ménard \& M. M. Shirley (red.), Handbook of New Institutional Economics (s. 727-786). Amsterdam: Springer. DOI: http://dx.doi.org/I0.I007/0-387-25092-I_29

Harling, P. (1996). The Waning of "Old Corruption". The Politics of Economical Reform in Britain 1779-1846. Oxford: Clarendon Press.

Harris, R. (2003). Political Corruption in and Beyond the Nation State. London: Routledge.

Hechter, M. (1992). "The Insufficiency of Game Theory for the Resolution of RealWorld Collective Action Problems”. Rationality and Society, 4 (I), 33-40. DOI: http://dx.doi.org/IO.II77/I04346319200400I005

Heckscher, G. (1952). Svensk statsförvaltning i arbete. Stockholm: Norstedt.

Helliwell, J. F. (2006). "Well-being, Social Capital and Public Policy: What's New?". The Economic Journal, II6 (5IO), $\mathrm{C}_{34}-\mathrm{C}_{45}$.

DOI: http://dx.doi.org/IO.IIII/j.I468-0297.2006.0I074.x

Hildebrand, E. (I896). Svenska statsförfattningens historiska utveckling frän äldsta tid till våra dagar. Stockholm: Norstedt.

Hodess, R., Banfield, J. \& Wolfe, T. (200I). Global Corruption Report 200I. Berlin: Transparency International.

Holmberg, S., Rothstein, B. \& Nasiritousi, N. (2009). "Quality of Government: What You Get". Annual Review of Political Science, I2, I35-I6I.

DoI: http://dx.doi.org/IO.II46/annurev-polisci-I00608-I045IO 
Hopkin, J. \& Rodríguez-Pose, A. (2007). "'Grabbing Hand' or 'Helping Hand'? Corruption and the Economic Role of the State". Governance, 20 (2), I87-208. DOI: http://dx.doi.org/IO.IIII/j.I468-049I.2007.00353.x

Jansson, T. (1985). Adertonhundratalets associationer. Uppsala: Almqvist \& Wiksell International.

Johnston, M. (2005). Syndromes of Corruption. Wealth, Power, and Democracy. Cambridge: Cambridge University Press.

Johnston, M. (2006). "From Thucydides to Mayor Daley: Bad Politics, and a Culture of Corruption?”. PS: Political Science \& Politics, 39 (4), 809-8I2. DoI: http://dx.doi.org/Io.IoI7/SI04909650606095I

Karklins, R. (2005). The System Made Me Do It. Corruption in Post-communist Societies. Armonk: M. E. Sharpe.

Kurer, O. (2005). "Corruption: An Alternative Approach to Its Definition and Measurement". Political Studies, 53 (I), 222-239. DOI: http://dx.doi.org/IO.IIII/j.I467-9248.2005.00525.x

Lichbach, M. I. (1997). The Co-operator's Dilemma. Ann Arbor: University of Michigan Press.

Lindroth, S. (1976). Uppsala universitet 1477-1977. Uppsala: Uppsala universitet.

Mauro, P. (I995). "Corruption and Growth". Quarterly Journal of Economics, IIO (3), 68I-7I2. DOI: http://dx.doi.org/I0.2307/2946696

Moran, M., Rein, M. \& Goodin, R. E. (2006). The Oxford Handbook of Public Policy. New York: Oxford University Press.

Mungiu-Pippidi, A. (2006). "Corruption: Diagnosis and Treatment". Journal of Democracy, 17 (3), 86-99. DOI: http://dx.doi.org/I0.I353/jod.2006.0050

Myrberg, I. (I922). "Bidrag till tjänsteackordens historia i vårt land”. Från den svenska statsförvaltningen, 5-6.

Nilsson, G. B. (200I). Grundaren. André Oscar Wallenberg (I8I6-I886). Stockholm: Carlsson.

North, D. C. (2006). "What is Missing from Political Economy". I: B. R. Weingast \& D. Wittman (red.), Handbook of Political Economy. Oxford: Oxford University Press.

North, D. C., Wallis, J. J. \& Weingast, B. R. (2009). Violence and Social Orders. A Conceptual Framework for Interpreting Recorded Human History. Cambridge: Cambridge University Press.

Offe, C. (2004). "Political Corruption: Conceptual and Practical Issues". I: S. RoseAckerman \& J. Kornai (red.), Building a Trustworthy State in Post-Socialist Transition (s. 77-99). New York: Palgrave Macmillan.

Olivecrona, K. (1859). Om den juridiska Undervisningen vid Universitetet $i$ Uppsala och om den Juridiska Fakultetens flyttande till Stockholm. Uppsala: Juridiska fakulteten.

Ostrom, E. (1998). "A Behavioral Approach to the Rational Choice Theory of Collective Action". American Political Science Review, 92 (I), I-22. DoI: http://dx.doi.org/Io.2307/2585925 
Peters, B. G., \& Pierre, J. (red.) (2002). Handbook of Public Administration. London: Sage Publications.

Pettersson, L. (1995). ”In Search of Respectability. Popular Movements in Scandinavian Democracy”. I: L. Rudebeck \& O. Törnqvist (red.), Democratization in the Third World. Uppsala: Department of Development studies, Uppsala University.

Pierson, P. (2004). Politics in Time. History, Institutions, and Social Analysis. Princeton: Princeton University Press.

Rawls, J. (1996). En teori om rättvisa. Göteborg: Daidalos.

Rhodes, R. A. W., Binder, S. A. \& Rockman, B. A. (2006). The Oxford Handbook of Political Institutions. Oxford: Oxford University Press.

Rodrik, D. (2007). One Economics, Many Recipes. Globalization, Institutions and Economic Growth. Princeton: Princeton University Press.

Root, H. L. (1996). Small Countries, Big Lessons. Governance and the Rise of East Asia. Hong Kong: Oxford University Press.

Rose-Ackerman, S. (2004). "Governance and Corruption”. I: B. Lomborg (red.), Global Crises, Global Solutions. Cambridge: Cambridge University Press.

Rothstein, B. (1998). "State Building and Capitalism: The Rise of the Swedish Bureaucracy". Scandinavian Political Studies, 2I (4), 287-306. DoI: http://dx.doi.org/Io.IIII/j.I467-9477.1998.tbooor6.x

Rothstein, B. (2000). "Trust, Social Dilemmas and Collective Memories". Journal of Theoretical Politics, I2 (4), 477-5OI. Dor: http://dx.doi.org/I0.1177/09516928000I2004007

Rothstein, B. \& Eek, D. (2006). Political Corruption and Social Trust. An Experimental Approach. Philadelphia: Annual Meeting of the American Political Science Association.

Rothstein, B. \& Teorell, J. (2008). "What Is Quality of Government? A Theory of Impartial Government Institutions". Governance, 2I (2), I65-190. DoI: http://dx.doi.org/Io.IIII/j.I468-049I.2008.0039I.x

Schelling, T. C. (1996). Social Mechanisms and Social Dynamics. Stockholm: Department of Sociology.

Shirley, M. M. (2005). "Institutions and Development”. I: C. Ménard \& M. M. Shirley (red.), Handbook of New Institutional Economics (s. 6II-638). Amsterdam: Springer.

Smith, B. C. (2007). Good Governance and Development. New York: Palgrave Macmillan.

Smith, D. Jordan (2007). A Culture of Corruption. Everyday Deception and Popular Discontent in Nigeria. Princeton: Princeton University Press.

Steinmo, S. \& Thelen, K. (1992). "Historical Institutionalism in Comparative Politics". I: S. Steinmo, K. Thelen \& F. Longstreth (red.), Structuring Politics. Historical Institutionalism in Comparative Analysis (s. I-32). New York: Cambridge University Press.

Strömberg, H. (200o). Allmän förvaltningsrätt. Malmö: Liber.

Tanzi, V. (2000). Policies, Institutions and the Dark Side of Economics. Northampton: Edward Elgar.

Teorell, J. (2007). Corruption as an Institution. Rethinking the Nature and Origins of the Grabbing Hand (Working paper 2007:5). Göteborg: The Quality of Government Institute. 
ARKIV | NR I

UNDP (2002). Human Development Report 2002 - Bosnia and Herzegovina. New York: United Nations Development Program.

Uslaner, E. M. (2008). Corruption, Inequality, and The rule of Law. The Bulging Pocket Makes the Easy Life. Cambridge: Cambridge University Press.

Världsbanken (200o). Anti-Corruption in Transition. A Contribution to the Policy Debate. Washington: World Bank.

Weis, E. (2005). Montgelas. Der Architekt des modernen bayerischen Staates 1799-I838. München: Beck Verlag.

Westerhult, B. (1965). Kronofogde, häradsskrivare, länsman. Den svenska fögderiförvaltningen I8I0-19I7. Lund: Gleerup.

Wrong, M. (2009). It's Our Turn to Eat. A Story of a Kenyan Whistle Blower. London: Fourth Estate.

You, J.-S. (2006). A Comparative Study of Income Inequality, Corruption and Social Trust. How Inequality and Corruption Reinforce Each Other and Erode Social Trust. Avhandling. Cambridge: Harvard University, Kennedy School of Government.

Young, H. P. (1998). Individual Strategy and Social Structure. An Evolutionary Theory of Institutions. Princeton: Princeton University Press. 


\section{Den socialdemokratiska staten}

Andra ombrutna och över

\section{Bo Rothstein}

Bo Rothstein är idag en av Sveriges ledande statsvetare. Hans avhandling, Den socialdemokratiska staten. Reformer och förvaltning inom svensk arbetsmarknads- och skolpolitik, som ursprungligen gavs ut 1986 blev startskottet för hans tre uppmärksammade arbeten om den moderna staten. I denna bok finns utgångspunkten för såväl Den korporativa staten som det mer programmatiska arbetet Vad bör staten göra?

\section{„Läs mer om boken på www.arkiv.nu»}




\section{Moderna klassiker}

\section{Arkiv förlag}

Hur ska vi gemensamt kunna använda och samtidigt vårda världens resurser på ett för framtiden hållbart sätt? I sin epokgörande bok Allmänningen som samhällsinstitution (Governing the Commons) utmanar Elinor Ostrom, som fick Nobelpriset i ekonomi 2009, de uppfattningar som bara ser två lösningar på "allmänningens tragedi": privatisering eller statlig reglering. Hon visar att människor genom frivillig organisering kan skapa livskraftiga institutioner som förmår att förvalta ömtåliga och knappa resurser. Ostroms teori har räckvidd och relevans långt utöver de sammanhang hon studerar.

Arkiv förlag 2009, 368 sidor 